\title{
Smart Environment Program, Smart Way to Smart City
}

\author{
Tutik Rachmawati ${ }^{1}$ \\ Priska Diah Pertiwi ${ }^{2}$
}

\begin{abstract}
Bandung City Government is ranked the $3^{\text {rd }}$ in smart city index in Indonesia only within 8 months of smart city application. Considering this achievement, it is necessary to study this fast-tracking success of smart city to enable a lesson learnt for other local governments. Hence, this research aims at evaluating the best practices of smart environment program as one of smart city projects and analyzing the positive transformation being brought. The analysis will be based on three core activities in smart environment: (1) the creation of thematic parks as open public spaces; (2) the restoration and the revitalization of rivers and its river banks; (3) urban gardening or urban farming. Combined with the result of extensive of literature review, this research will apply eight (8) aspects of smart environment. These aspects are (1) The Provision of Public Open Space; (2) Good Waste Management; (3) Slum Areas Management; (4) The Revitalization of River; (5) Eliminate "Chopsticks Syndrome" in Building Construction; (6) Alternative energy; (7) Reducing the Production of CO2; (8) Urban Farming.

A qualitative research method were used in this research. The analysis of this research is a comparative analysis, with the use of smart city best practices in other cities in other countries as the benchmark. Seven local government work units/departments/agencies of Bandung City which play important role as the leading sectors of the smart environment program were the key resources of this research. The data were collected from 30 interviews. This research gave its reader a new perspective in understanding the concept and the practices of smart city in the public administration perspective.
\end{abstract}

\section{Keywords:}

innovation; smart city; smart environment program.

\begin{abstract}
Abstrak
Pemerintah Kota Bandung menghasilkan prestasi yang luar biasa yaitu menduduki peringkat ke-3 dalam indeks kota Cerdas Indonesia hanya dalam waktu delapan bulan sejak diterapkannya kota cerdas. Penelitian ini bertujuan untuk memahami bagaimana praktik baik dalam bidang smart environment 'ingkungan cerdas' sebagai salah satu program smart city pemerintah Kota Bandung tersebut dan melakukan analisa perubahan positif apa saja yang dihasilkan dari program tersebut. Analisa dalam penelitian ini akan didasarkan pada tiga aktivitas utama dalam 'lingkungan cerdas' yaitu (1) penciptaan taman tematik sebagai ruang terbuka hijau; (2) restorasi dan revitalisasi sungai dan pinggiran sungai; (3) kebun kita atau taman kota. Digabungkan dengan hasil dari studi pustaka, maka penelitian ini akan menggunakan 8 aspek sebagai alat analisa, yaitu (1) penyediaan ruang terbuka; (2) manajemen pengelolaan sampah; (3) manajemen daerah kumuh; (4) revitalisasi sungai; (5) menghilangkan sindrom sumpit dalam pembangunan gedung; (6) energy alternative; (7) mengurangi produksi C02 dan (8) kebun kota.

Penelitian ini merupakan penelitian kualitatif dengan menggunakan alat analisa perbandingan dan analisa metode dan standar praktik baik (benchmarking) smart cities di kota-kota lain di Indonesia. Tujuh (7)
\end{abstract}

\footnotetext{
${ }^{1}$ Public Administration Department - Parahyangan Catholic University.

Email: rachmawati.tutik@gmail.com

${ }^{2}$ Public Administration Department - Parahyangan Catholic University.
} 
Satuan Kerja Perangkat Daerah (SKPD) yang merupakan SKPD utama pelaksana smart cities digunakan sebagai informan utama dalam penelitian ini. Data-data dikumpulkan dari hasil 30 wawancara. Hasil dari penelitian ini memberikan perspektif baru dalam memahami konsep dan praktik smart cities dalam perspektik administrasi publik.

\section{Kata Kunci:}

inovasi; kota cerdas; program lingkungan cerdas.

\section{Introduction}

Bandung as also other cities in Indonesia is the center of attraction of human movement, be it from other cities or from other rural areas (urbanization). As the center of human movement, most of non-renewable energy and resources consumptions are concentrated here. Hence, it impacted the city capacity to provide energy and resources to its people. Badan Pusat Statistik' Data shows the increased number of population in Bandung. In 2011 the population in Bandung is 2.424 .957 and year 2014 it increases to 2.470.802, within 3 years, the population in Bandung City has increased for 45.845 and this increase will be more likely to rocket in the next millennia.

The higher the population in a city will mean higher burden to the city environment. More people means more waste, more housing needed, more land for the settlement, more water and electricity provision. In this dire situation, a good spatial planning has become an urgency. Using the latest development of information and communication technology, urban spatial planning is reflected in smart city concept (Anthopoulos \& Vakali, 2012).

According to IBM Institute for Business Value (2009) Smart City is the use of new technology to change the city system, its operation, and method of services provision. In smart city, data (big data) is gathered easily, better analyzed and at the end, it accelerate the decision-making process in the city government. Bolivar (2015) define smart city as the incorporation of complex Information \& Technology (IT) into solutions for equally complex problems. Never before could IT have been more increasingly significant for harnessing the city resources, new technology, and innovation and limited budget so that it could change challenges into opportunities. Smart City is expected to be able to increase quality of life in the city and encouraging the collaboration and involvement among government, institution, and citizen.

This paper analyzes the implementation of smart environment program which has become important part of smart city policy in Bandung City. Smart city become the strategic planning of Bandung City Government for the year 2013 to 2018 to find alternative solutions to the environmental problems. As part of smart city, smart environment program is equally important particularly on the ground that Bandung City Government need to have good environmental management. Through smart environment program, Government of Bandung undertook various programs and activities to improve the environmental quality such as (1) the creation of thematic parks as open spaces; (2) the restoration and the revitalization of rivers; (3) urban farming. The analysis of the smart environment implementation was drawn from on smart city index of in cities throughout Indonesia.

\section{Research Method}

The design of this research is a qualitative research and the analysis of this research will be a descriptive qualitative analysis. Data collection was done through interviews and observation in several sites within Bandung City in which eight initiatives of smart environment took place. There were 
30 interviews from which the researcher drew the analysis of smart environment. The researchers conducted purposive sampling technique to determine the 30 interviewees. The interviewees were selected to represent three groups; (1) local government work unit (Satuan Kerja Perangkat Daerah/SKPD) who play the role of leading sector in smart environment program; (2) community members who were benefiting the smart environment program (thematic park visitors) and (3) community members who were involved in Gardening Village Program.

\section{Literature Review}

\section{Smart Cities and Smart Environment}

Bolivar (2015) argue that smart cities could be conceptualized in different ways, from the intensive use of IT in urban contexts, to the generation of innovative services, organizational capabilities and physical infrastructure. In a nutshell, smart city is an effort to make every cities smarter both technological and social; from improving convenience, facilitating mobility, creating process, efficiencies, conserving energy, improving the quality of air and water, identifying problems and fixing them quickly recovering rapidly from disasters, collecting data to make better decisions, deploying resource effectively and sharing data to enable collaboration across entities and domains (Caragliu et al. 2011; Schaffers et al. 2011).

Gill-Garcia, Pardo \& Nam (eds. 2016) argue that smart cities should be studied and analyzed on the basis of multiple components. These components are (Chourabi et al. 2012; Gil-Garcia 2012; Gil-Garcia et al. 2014; Nam and Pardo 2014): (1) public services; (2) city administration and management; (3) policies and other institutional arrangements; (4) governance, engagement and collaboration; (5) human capital and creativity; (6) knowledge economy and pro-business environment; (7) built environment and city infrastructure;
(8) natural environment and ecological sustainability; (9) ICT and other technologies; and (10) data and information.

Smart environment rooted its basis of smart cities components no. 7 and no. 8 which requires city to have proper infrastructure such as roads, bridges, tunnels, building (residential, business and recreational), pipelines, electrical and communication lines and so forth in terms of economic sustainability and management challenges (Kaklauskas et al. 2009; Kim 2010; Lin 2007; Moser 2010; van Heur 2010; Wang 2011). Smart environment also focus on natural environment and ecological implications of urban growth and development (Hollands 2008, p.310).

Further, European Union Project for Smart City (www.smart-cities.eu) provides characteristics and factors for smart city as an indicators and assessment framework to assess city's performance as smart city. These characteristics are (1) smart economy, including factors of economic competitiveness such as innovation, entrepreneurship, trademarks, productivity, and flexibility of the labour market; (2) smart people such as the level of qualification or education of the citizens but also the quality of social interactions regarding integration and public life and the openness towards the 'outer' world; (3) smart governance which comprise aspects of political participation, services for citizens as well as the functioning of the administration; (4) smart mobility: local and international accessibility are important aspects of mobility as well as the availability of information and communication technologies and modern and sustainable transport systems; (5) smart environment, is described by the attractive natural conditions (climate, green space, etc.), pollution, resource management, and also by efforts towards environmental protection and (6) smart living: comprises various aspects of quality of life such as culture, health, safety, housing, tourism (Giffinger et al. 2007). 


\section{Aspects of Smart Environment}

Smart Environment program by the City of Amsterdam - The Netherlands was implemented through the Climate Street Program. This is an innovative program as part of climate change mitigation by ways of reducing the $\mathrm{CO} 2$ level and creating alternative renewable energies. Initiatives under this program are ranging from the use of high-tech scan device to map the energy saving potentials, the use of smart electricity plug which enable lights to dim of turned-off automatically, energy-saving Street lighting, to the use of electric vehicles in waste collection to minimize $\mathrm{CO} 2$ emissions.

In this research, a literature study was done to establish a framework to the concept of smart environment based on the practices of cities throughout Indonesia. The researchers used special report publications on smart cities by KOMPAS from March 2015 - August 2015 to define the index of smart environment in Indonesia. These special report publications were part of initiatives by three parties: KOMPAS daily, PT Perusahaan Gas Negara (Persero)/State Gas Company and the Institut Teknologi Bandung (ITB). Based on the practice of Smart Cities Indonesia (Kompas, 2015), we set the following indicators of Smart Environment:

\section{a. The Provision of Public Open Space}

Public Open Space should meet the needs of its citizens. Ideally, it should cover at least $30 \%$ of the size of the city (based on the Minister of Public Works No. 5 of 2008) and consider the number of population as well. Public open space has not only an ecological, social cultural, economic functions, and but also aesthetic functions.

\section{b. Good Waste Management}

Sewage and waste disposal, derived from households or factories should not directly discharge into the river. There must be a special designated plant to manage and process the waste and garbage. Further, waste can be processed into energy and recycled into items valuable.

\section{c. Slum Areas Management}

Slum areas, as in generally found in urban area, normally occupy the riverbanks and other state-owned lands. The presence of slums can damage the visual layout of the city and causing an environmental crisis since it impede the flow of river water when it rains and consequently causing flood. In these areas, river has to endure the burden of the garbage and waste of human activities. It is then thought to be an urgency to better manage the slum areas for the sake of the river and other parts of the city. One of the alternatives to reduce the burden to the river is to move the people inhabit the slums area (riverbank) to better and safer housing such as flats or apartment.

\section{d. The Revitalization of River}

This initiative is related to the slum areas management. As it was mention above, it is common that the rivers of the city in Indonesia are usually serve as a rubbish bin for the inhabitants in its riverbank. As part of the smart environment program, it is necessary to bring back the very basic function of the river in a city as an ecosystem that support the city environment and further provide public open space.

\section{e. Eliminate "Chopsticks Syndrome" in Building Construction}

Chopsticks syndrome is considered as a tragedy for any urban planner. It explains the loss of historical buildings and replaced by new buildings or properties with commercial purpose (Budihardjo, 2014). Chopsticks syndrome cause historical loss due to the building's history that became the pride of being replaced by commercial buildings who are only after profit. Chopsticks syndrome also occurs when (high-rise) buildings are constructed in areas with a high population 
density only and this create imbalance physical and infrastructure development in the city.

\section{f. Alternative energy}

Initiatives to find for alternative energy sources that are more efficient and environmental friendly are important part of smart environment program. In a city in which densely populated, it will difficult to meet the energy needs of every households and companies. As it always suggested, it is important to find sustainable and renewable energy for a city to be sustained. Hence, it is urgent to find alternative energy resources.

\section{g. Reducing the Production of $\mathrm{CO} 2$}

Everywhere in the world, urban areas are in danger of high level of pollution which has become the consequences of human activity in the city. Air pollution, particularly marked by the high level of carbon dioxide (CO2) will soon create negative impacts for the human beings. At foremost, the decline of oxygen $(\mathrm{O} 2)$ quality affect the population health. It is common to find urban inhabitant with illness such as ASPA or even worse lung cancer. To overcome this problem, city government should take up measures in reducing the impact of $\mathrm{CO} 2$ production. These measures can be started with the programs such as tree planting, public transportation use or bicycles to get around the city, and vehicle emissions test

\section{h. Urban Farming}

Urban area as the center of attraction for people mobility face the challenge of lack of space, both for the population and for the environment itself. Initiative to use of the space in urban area efficiently should be every city's priority. Hence, any vacant land in every urban neighborhood should not be left idle, but it should be used efficiently as spots for urban farming. Not only it will add aesthetic values to the face of the urban area, it will also to contribute to lower the high level of Co2 and provide green open space.

Eight initiatives elaborated above became the framework of this research to analyze the smart environment program within smart city policy in every city in Indonesia.

\section{Discussion}

Based on interviews and observation, this section will focus on the analysis of the research finding using the framework set in the literature review. Various programs and activities were done by the Bandung City Government since 2013. These activities were carried out in collaboration with State-Owned Enterprises/Regional-Owned Enterprises and private sector, as well as the Bandung City Government citizens. Using the framework of eight initiatives in smart environment, below are the activities conducted in Bandung City Government as the Smart Environment Program:

\section{The provision of open public \& green space}

Act no. 26 Year 2007 about Spatial Planning requires every city (urban) or District (rural) has open green space of at least 30 percent of the total number of the area. This number will have to consist of $20 \%$ Public (local government owned) Open green space (Ruang Terbuka Hijau) 10\% of private owned. In 2011 there was 1910.49 hectares of green open space, which is $11.43 \%$ of the area of the city. However, based on the Green Open Space Master Plan for the year 2012 to 2032 and based on Long and Middle Term Development Goal of Bandung City year 2013-2018, the number of green open space is set to $28 \%$.

However, the limited space and land makes the Mayor -Ridwan Kamil- seek other alternatives to increase the public and green open space by constructing parks, and to make it more interesting, the park has been set into themes and since then on, the mayor is famous of really keen on building thematic parks. All 
the parks in Bandung City has been undergoing face-lift and renovation. Further, any possible space such as road-side (pedestrian path), space under flyover bridge are being planted with trees. Up to now, Bandung City has 19 thematic parks/gardens. The idea of the park theme, mostly came from the Mayor -Ridwan Kamilhimself, few other ideas come from the people who posted their ideas through twitter. In this case, there are participation and engagement from the Bandung City Citizen. Further, at the Neighborhood Association (RW) level, the Bandung City Government set a program, - 1 park for $1 \mathrm{RW}-$, to provide more playground for children. According the Office of Cemetery and Landscaping, in 2015, the city of Bandung had about 613 RW parks.

\section{Waste Management}

In order to have better waste management, Bandung City Government provided sufficient waste bins and being put in every possible corner throughout Bandung City territory. Bandung City Government worked with two other agencies: Regional State Owned Company (Perusahaan Daerah/PD) Kebersihan and Regional Environmental Energy (Badan Pengelola Lingkungan Hidup/BPLH). BPLH is in charge with provide the waste bins annually and PD Kebersihan responsibility is to distribute those waste bins. In 2013, BPLH was able to produce a waste bag made of biodegradable (tapioca starch). The waste bins were available in two types (organic and inorganic) waste bags. Bandung City Government, targeted a 5000 points for waste bins and the priority is in every main road of Bandung territory. Private sectors were also involved in this initiative. Below is the table which show the contribution of private sectors in Bandung City's waste management.

Since June 2014, BPLH has started an environmental campaign 'Trash Pick Movement' (or Gerakan Pungut Sampah/GPS) to all Bandung City Government citizen. Under
Table 1.

Private Sector Contribution in Waste Management

\begin{tabular}{cll}
\hline No. & Private Sector's Name & Type of contribution \\
\hline 1. & Bank Mandiri-PT. & Trash cans 2 in 1 \\
& T-Files Indonesia & (Monster) , 114 Units \\
2. & CV. Butterfly Fathunnaf & Trashbag, 5000 sheet \\
& Center & \\
3. & PT. Moradi & Trash Cans 2 colors (50 \\
& & Litre Capacity), 100 set \\
\hline
\end{tabular}

Source: Laporan Kinerja PD Kebersihan Tahun 2014

this campaign, every Monday, Wednesday and Friday citizen all over Bandung City is encourage to spend 10-30 minutes to clean their surrounding from trash and pick up all the spotted trash. This campaign aimed at reducing the amount of garbage throughout Bandung City.

BPLH was also in charge of providing and distributing bio-digesters to the citizens in Bandung City Territory. Bio-digester is a very smart machine that turn organic waste into a biogas which then can be used for cooking and other energy needs. It is stated in the Long \& Medium Term of development (Rencana Jangka Panjang \& Jangka Menengah Daerah/RPJMD) of Bandung City in 2013-2018 that 10,000 biodigesters will be given to each neighborhood associations (Rukun Tetangga/RTs) in the city of Bandung. So far, in 2015, there are bio-digesters which has been distributed to 57 RTs out 100 targeted number.

Further, the provision of waste bins were completed with the establishment of 'Bank Sampah' which can be translated as 'trash bank'. By its name, it is a type of community bank in which community can deposit, not their money, but their trash, which will be exchanged for money or other necessities goods for their households. The trash will be then processed and recycled as raw material for handicraft with an economic value. This trash bank was initiated by PD Kebersihan in February 1, 2015 and called 'Bank Sampah Resik', based on the Directors of PD Kebersihan Regulations No. 
6/2015. The establishment of the trash bank is also in accordance with the Regulation of the Minister of Environment Number 13/2012 about 3R (Reduce, Reuse \& Recycle).

Apart from Bank Sampah Resik, there is also another trash bank that is managed by a Non Governmental Organisation (NGO) called Bank Sampah Hijau Lestari (Hijau Lestari Trash Bank). However, Bank Sampah Hijau Lestari is supported by BPLHBandung and Department of Agriculture and Food Security. These two agencies supported the Bank Sampah Hijau Lestari (BSHL) by providing training in gardening and processing organic waste into organic fertilizer and biogas. Since the establishment in 2015, BSHL is able to create 100 trash banks throughout Bandung City territory.

Another initiative by PD Kebersihan in waste management was the integration of Tempat Pembuangan Sampah Sementara/TPS (or temporary dumpsters) throughout Bandung City territory and the use of Bio-digester. The integration of TPS increased the number of waste/trash being able to be accommodated and processed. Data from PD kebersihan shows that in 2015, there were 5 temporary dumpsters that were able to manage 8 tons/day. Two temporary dumpsters with bio-digester (TPS Sekelimus and TPS Babakan Sari) were able to process 146.5 tons of trash per day. Hence, the amount of organic waste reduction during 2015 was 154.5 tons / day. This means that in 2015, Bandung City was able to reduce up to $0.18 \%$ trash that goes to dumpster.

\section{Slum Areas Management}

Slums in urban area in Indonesia are generally situated in a plot of illegal land such as the riverbank areas in which by law it is forbidden to be used as human settlement. In Bandung city territory however, slums area are also situated in legal human settlement but with unhygienic environment and terrible basic infrastructure provision. Based on data released by the Department of Human
Settlements and Spatial Planning of Bandung City Government, in 2015 there are 453 slums areas covering 1,457.45 hectares. These slums area are characterized by the lack of clean water provision (less than 30\%), low quality of drainage system, low quality of road (more than $70 \%$ of road is in bad condition), and highly populated (high level of population density with more than 100 houses in one hectare).

The solution to this problem of slums areas is to build vertical building to re-settle people living in the slums area. However, to build this vertical building (rumah susun/ rusun), an important aspect e.i. access to public transportation must be taken into account. Having understood that human relocation will brings dynamic changes to the lives of many people, Bandung City Government has prepared a transit flat housing (transit apartment). The goal of Bandung City Government is to build 15 apartments by the end of 2018. However, during this research was conducted, there is only one apartment being constructed. This apartment will consist of 1000 units with an ownership of 60 years. Following this, another 12 Apartement Rakyat (community apartment) in 12 different locations will be constructed and the works will be procured to private sector. The construction of Apartment Rakyat is considered as an innovation in overcoming the problem of slums. Further, Bandung City Government is regarded as the standard for benchmarking for other local governments in this regards. With the ownership right last up to 60 years (this is significantly longer than other general apartment which last only 5-6 years), it will provide the poor with an asset.

As an addition to the building vertical housing, in 2017, Department of Human Settlements and Spatial Planning of Bandung City Government aims at improving 1,035 nonlivable housing (rumah tidak layak huni). This is called slums upgrading program, with a total budget of IDR 7 billions, each non-livable house will receive about IDR 5-15 millions. 
Table 2.

Development Concept to Avoid Chopstick Syndrome

\begin{tabular}{clll}
\hline No. & $\begin{array}{c}\text { Sub-Area of the City } \\
(\text { Sub Wilayah Kota/SWK) })\end{array}$ & Concepts & \multicolumn{1}{c}{ Tujuan Penataan Ruang } \\
\hline 1. & Bojonagara & Aerobiopolis & Perlindungan Kawasan Bandara dan Industri Strategis \\
2. & Cibeunying & Travelapolis & Perlindungan Bangunan Heritage dan Pusat Kuliner \\
3. & Tegalega & Mediapolis & Pengembangan Industri Kreatif \\
4. & Karees & Karyapolis & Pengembangan Kawasan Kreatif Terpadu \\
5. & Arcamanik & Sportipolis & Pengembangan Pusat Pembinaan Potensi Olahraga \\
6. & Ujungberung & Sundapolis & Pengembangan Seni Budaya Berbasis Masyarakat \\
7. & Kordon & Eksibisiopolis & $\begin{array}{l}\text { Pengembangan Fasilitas dan Penyelenggaraan Event-event } \\
\text { Etalase Produk Karya dan Jasa }\end{array}$ \\
8. & Gedebage & Teknopolis & $\begin{array}{l}\text { Pengembangan Kawasan yang bersinergikan Antara Pendidikan } \\
\text { Tinggi, Ekonomi Kreatif, Komersial dan Pusat Pemerintahan. }\end{array}$ \\
\hline
\end{tabular}

Source: Research results

\section{Cikapundung River Restoration}

Cikapundung River is one of seven rivers streaming across Bandung City Government territory. Among those rivers, Cikapundung River is the most polluted and its river bank is the most populated. The initiatives from the Bandung City Government to restore the river to its pristine condition to achieve good river habitat is regarded as one aspect of smart environment program. Cikapundung river was cleaned from all the trash, its river bank was restored from theillegal building, re-constructed and beautified into a nice river terrace called Cikapundung Terrace. This project was funded by national budget (Anggaraan Pendapatan dan Belanja Negara/APBN) and construction was done in cooperation among Ministry of Public Works, West Java Provincial Government, and Bandung Institute of Technology. The Mayor -Ridwan Kamil- himself was the consulted in the design of this Cikapundung Terrace. Cikapundung Terrace is intended as an open public space in which community is able to conduct social activities. CIkapundung terrace is also used as an education means to educate the community about the importance to keep the river clean from the trash and pollution.

Apart from Cikapundung River, the river restoration was also done to Cikapayang river. In Cikapayang River, the river restoration took a a form of water purification project. The restoration include various works such as installing water purifier, clear out the river bank and built a river border.

\section{Avoiding "Chopsticks Syndrome"}

Chopsticks syndrome is a tragedy of the loss of historic old buildings and replaced by modern new buildings or properties with commercial purpose. To avoid chopsticks syndrome Bandung city government, in its spatial plan 2015-2035 Bandung city is divided into 8 regions:

The purpose of the spatial planning that divide the area of city into eight sub areas is to balance the physical and other supported infrastructure within the city. The balance development will increase the economic potential of each region.

Sub Wilayah Kota (SWK) is also regarded an innovation for the smart environment program. The mayor, Ridwan Kamil, has been working together with Development Planning Board (Badan Perencanaan Pembangunan Daerah) and the Department of Spatial Planning and Human Settlements (Distarcip). Among those eight concepts of development, SWK teknopolis Gedebage is the priority. SWK Teknopolis Gedebage is expected to be the icon of Bandung City. 


\section{Alternative energy}

As part of the initiative to find alternative energy, Bandung City Government used biodigester to process organic wastes and turn them into energy (methane gas/biogas \& organic liquid fertilizer). Regional Environmental Energy (Badan Pengelola Lingkungan Hidup/ $\mathrm{BPLH})$ is the agency in charge of these biodigester instalations. Through the Zero Waste Home program, BPLH distribute the biodigester units to the community in RT/RW level that produce organic waste up to $150 \mathrm{Kg} /$ day. The latest data in 2015, there were 57 new biodigester distributed to the RT / RW from an initial target of 100 . This number is expected to increase in the coming years.

\section{Reducing the Production of Co2}

The activities under the initiative to reduce the production of $\mathrm{Co} 2$ are carried out regularly. One of the activities is tree planting (undertaken by the Department of Agriculture and Food Security, Department of Cemeteries and Parks and BPLH). Based on data from the Department of Cemeteries and Parks in 2012 trees were 236,840 trees to be planted. In 2013 as many as 246,572 trees, and in 2014 as many as 18,508 trees were being planted.

The mayor issued a mayor regulation of No. 572 Year 2010 which regulate the threshold of Vehicle Exhaust Emissions. As the result of this regulation, there are 55 car workshops that run vehicle emissions examination. This initiatives aims at increasing the level of awareness of the vehicle owner to regularly test their vehicle emissions and keep it below the threshold.

Another effort undertaken by Bandung City Government to reduce vehicle emission is to have Car Free Day in several main roads in Bandung territories such as Ir H. Juanda Street, Merdeka Street and Buah Batu Street every Sunday morning from 06:00 to 10:00 am. And also, since 2015, Bandung City Government conducted Car Free Night in Asia and Africa
Street every Saturday night (18:00 pm) until Sunday at 11:00 pm.

Further, community and other nongovernmental organization contribute to the initiatives to reduce the $\mathrm{CO} 2$ production. Bandung Creative City Forum (BCCF) has initiated bike.bdg which provide bikes for rent for Bandung community to travel within Bandung City. Based on the interview with one of the officers in bike.bdg, there are five shelters in which community can rent bike, such as campus of Bandung Institute of Technology, Balubur, Cikapayang Park, Unikom, and Flexi Park. With a total number of 170 bikes, community can rent a bike for only IDR 3,000/ hour.

\section{Urban Farming}

Urban Farming is a movement (as part of smart environment program) which focus on making the best use of any vacant space in the city regions as a planting space. In urban farming, commercial crops such as vegetables and fruits are planted in the community neighborhoods. Urban farming began in 2014 with $151 \mathrm{RW}$ as the pioneers. Urban farming at the neighborhood level (RT/RW) was the mayor idea. The Department of Agriculture and Food Security is the leading sector for this urban farming. Many free trainings (such as hydroponic and vertical gardening method) were provided for the community member who are interesting to do urban farming. To accommodate the harvest, Bandung City Government initiated Bandung Agri Market, in which urban farmers can display their produce and get customers to buy their produces.

\section{Conclusion}

Using the eight steps of smart environment framework, this research provided insights into what types of initiatives conducted by Bandung City Government in realizing smart environment within smart 
city concept. All the initiatives are in their early stage, therefore another research using wider and deeper framework should be done to evaluate the smart environment program. The good practice that can be understood from this research is the success of Bandung City Government to constitute good cooperation with other agencies within the governments and with other higher level of government (national government and other local governments), and also with third parties such as private sectors and NGOs. Further, every initiatives were characterized with the community engagement which contribute to its success.

However, to guarantee the realization of smart environment, the researchers recommend several aspects as below:

a. Bandung City Government needs to increase the area of green open space from $11.43 \%$ to $30 \%$ and hence will be able to meet the standard of 5018.9 hectares.

b. It is an urgency for Bandung City government to monitor the maintenance of distributed waste bins to minimize the damage. This will also reduce the amount of money spent to replace the damaged bins. There are also a need to educate the community to contribute to the maintenance of these waste bins and other public facilities.

c. It is important for the Bandung City Government to build partnership with research institutes, higher education institutions, as well as state / local enterprises to continuously seeking alternative energies. For the bio-digester initiative, there is a need to scale-up the coverage of the bio-digester not only in the neighborhood level (RT/RW) but to whole area of the city e.i. the construction of the Power Plant Waste Plant (SPP) which is able to generate electricity for city.

\section{References}

Anthopoulas, Leonidas G \& Vakali, Athena (2012). Urban Planning and Smart Cities: Interrelations and Reciprocities. In Alvarez F. et al (Eds.), The Future Internet, 7281, pp. 178-189.

Bolivar, Manuel P.R. (2015). Transforming City Governments for Successful Smart Cities. In Bolivar, Manuel P.R (Eds.), Cham: Springer.

Budihardjo, Eko. (2014). Reformasi Perkotaan: Mencegah Wilayah Urban Menjadi Human Zoo. Jakarta: Penerbit Buku Kompas.

Caragliu, A., Del Bo, C., \& Nijkamp, P. (2011). Smart Cities in Europe. Journal of Urban Technology, 18(2), pp. 65-82.

Chourabi, H., Nam, T., Walker, S., Gil-Garcia, J. R., Mellouli, S., Nahon, K., Pardo, T. A., \& Scholl, H. J. (2012). Understanding smart cities: An integrative framework. Proceedings of the 45th HICSS, IEEE, 2289-2297.

Giffinger, R., Fertner, C., Kramar, H., Meijers, E., \& Pichler-Milanović, N. (2007). Smart Cities: Ranking of European Medium-sized Cities. Vienna, from http://www.smart-cities.eu/ download/smart_cities_final_report.pdf.

Gil-Garcia, J. R. (2012). Towards a smart state? Inter-agency collaboration, information integration, and beyond. Information Polity, 17(3), pp. 269-280.

Gil-Garcia, J. R., Helbig, N., \& Ojo, A. (2014). Being smart: Emerging technologies and innovation in the public sector. Government Information Quarterly, 31(S1), 11-18.

Gill-Garcia J.R., Pardo, Theresa A., \& Nam, Taewoo (eds. 2016). Smarter as the new urban agenda: a comprehensive view of the $21^{\text {st }}$ century city. Springer.

Hollands, R. G. (2008). Will the Real Smart City please stand up? Intelligent, progressive or 
entrepreneurial. City: Analysis of Urban Trrends, Culture, Theory, Policy and Action, 12(3), pp. 37-41.

Kaklauskas, A., Zavadskas, E. K., \& Šaparauskas, J. (2009). Conceptual Modeling of Sustainable Development. Technological \& Economic Development of Economy, 15(1), pp. 154-177.

Kim, C. (2010). Place Promotion and Symbolic Characterization of New Songdo City, South Korea. Cities, 27(1), pp. 13-19.

Lin, Z. (2007). From megastructure to megalopolis: Formation and transformation of megaprojects in Tokyo Bay. Journal of Urban Design, 12(1), 73-92.

Moser, S. (2010). Putrajaya: Malaysia's New Federal Administrative Capital. Cities, 27(4), 285-297.

Nam, T., \& Pardo, T. A. (2014). The changing face of a city government: A case of Philly311. Government Information Quarterly, 31(Supplement), S1-S9.

Schaffers, H., Komninos, N., Pallot, M., Trousse, B., Nilsson, M., \& Oliveira, A. (2011). Smart cities and the future internet: Towards cooperation frameworks for open innovation. In J. Domingue, A. Galis, A. Gavras, T. Zahariadis, \& D. Lambert (Eds.), The future internet (pp. 431-446). Heidelberg: Springer

Van Heur, B. (2010). The Built Environment of Higher Education and Research:
Architecture and the Expectation of Innovation. Geography Compass, 4(12), 1713-1724.

Wang, S. W. (2011). The Evolution of Housing Renewal in Shanghai, 1990-2010: A 'socially conscious' entrepreneurial city? International Journal of Housing Policy, 11(1), 51-69.

\section{Internet sources}

European Union Project for Smart City (www. smart-cities.eu)

BPS. (2014). Jumlah Penduduk Menurut Jenis Kelamin Dan Kecamatan Di Kota Bandung 2011-2014. (Online). (https://bandungkota. bps.go.id/linkTableDinamis/view/id/9)

International Business Machines Corporation. Analyzing The Future Of Cities", What is a smarter city?. (Online). (http://www.ibm. com/smarterplanet/us/en/smarter_cities/ overview/, accessed October 26 Oktober 2015)

IBM Institute for Business Value. (2009). How smart is your city? Helping cities measure progress. IBM Corporation.

IBM Institute for Business Value (2009). A vision of smarter cities: how cities can lead the way into a prosperous and sustainable future. IBM Corporation.

http://amsterdamsmartcity.com/projects/ detail/id/9/slug/climate-street

http://lipsus.kompas.com/kotacerdas 